\title{
When crises collide-Policing a pandemic during social unrest
}

\author{
Marie C. Jipguep-Akhtar, ${ }^{\star}$ Tia Dickerson, ${ }^{\star}$ and Denae L. Bradley*
}

This article is related directly to the $6^{\text {th }}$ International Law Enforcement $\mathcal{E}$ Public Health (LEPH) Virtual Conference in March 2021.

\begin{abstract}
In 2020, the United States was shaken by concurrent crises: the COVID-19 pandemic and protests for racial equality. Both crises present significant challenges for law enforcement. On the one hand, the protests for racial equality drew the public's attention to the criminal justice system's disparate treatment of Blacks and other people of colour. On the other hand, the pandemic required the expansion of police duties to enforce public health mandates. To ensure compliance, law enforcement may arrest, detain, and even use force to prevent the transmission of communicable diseases that may have an irreversible impact on human health, such as COVID-19. Policing, however, is at a critical point in America. The government is expanding police powers for the sake of public health; all the while, public indignation about police (ab)uses of power has fuelled calls for its defunding. It is therefore important to explore Americans' views of policing pandemics during periods of social unrest, focusing on the recognition that socio-economic and racial inequities shape perceptions. The data from this project derives from surveys with Americans on the specific topics of race, policing, racial protests, and COVID-19. The study finds that Americans perceive the police as legitimate overall; however, there are divergences based on race, gender, and marital status. These differences may contribute meaningful insights to the current discourse on police legitimacy in America.
\end{abstract}

Key Words COVID-19 pandemic; perceptions of the police; racial protests.

\section{INTRODUCTION}

In democratic societies, the public's trust is essential for a legitimate model of policing (Pica et al., 2019). Legitimacy is a facet of authority that leads individuals to believe that authority is entitled to be deferred to and obeyed (Sunshine \& Tyler, 2003). More importantly, legitimacy promotes cooperation and compliance, fostering greater satisfaction with the police (Henry \& Franklin, 2019; Hinds \& Murphy, 2007). Yet one of the biggest challenges that police face today is a lack of legitimacy (Jones, 2020).

The COVID-19 pandemic and the racial protests of 2020 reinvigorated the debate on police legitimacy in the United States. One reason is that law enforcement agencies are treading on unknown territory and have no blueprint for how to manage the epidemic and its consequences (Jones, 2020). Their responses change as the government receives information from epidemiologists and virologists on how to manage the pandemic. Similarly, law enforcement's handling of protests varies as they try to balance safety concerns with the public's First Amendment right to peacefully assemble (Metcalfe \& Pickett, 2021). Their reactions range from supporting protesters to dispersing them with tear gas, to shooting them in the head or neck with rubber bullets (Szabo et al., 2020). The contentious climate that surrounded the 2020 presidential election also revived the debate on police legitimacy in the United States. Whereas the incumbent presented himself as the candidate of "law and order" amid US protests against police brutality and racial injustice, his challenger called for reducing police use of force and increasing community policing.

The function of police during a pandemic - just as in the absence of a pandemic-is to protect the community, but the pandemic adds a new threat to public safety besides crime and disorder: a deadly virus (Bittner, 1970; Nix et al., 2021). In the case of protest policing, the pro-social function of legitimacy is clearly tangible. Policing that is deemed

Correspondence to: Tia Dickerson, Department of Sociology and Criminology, Howard University, P.O. Box 987, Washington, DC 20059, USA. E-mail: tia.dickerson@ bison.howard.edu

To cite: Jipguep-Akhtar, M. C., Dickerson, T., \& Bradley, D. L. (2021). When crises collide-Policing a pandemic during social unrest. Journal of Community Safety and Well-Being, 6(3), 97-103. https://doi.org/10.35502/jcswb.199

@ Author(s) 2021. Open Access. This work is distributed under the Creative Commons BY-NC-ND license. For commercial re-use, please contact sales@sgpublishing.ca. g.PUBLISHING Published by SG Publishing Inc. CSKA Official publication of the Community Safety Knowledge Alliance. 
legitimate is liable to sustain peaceful protest whereas a lack of perceived legitimacy may catalyze immediate and sizable conflict (Hoggett \& Stott, 2010; Murray, 2010). There is a robust literature on people's opinions and attitudes towards the police that has assessed how people of various demographics (e.g., race and gender) feel about the police and measured people's perceptions of police conduct, appropriateness, and legitimacy (Culhane et al., 2016; Pica et al., 2019; Wortley \& Owusu-Bempah, 2009). However, police legitimacy, and specifically whether the police response to public health emergencies and racial protests is rightful, proper, or suitable, is understudied (Johnson et al., 2014; Maguire, 2015).

\section{The Present Study}

We seldom experience health and social crises of a prolonged nature that would confront the public, nationally, with an expanded use of police powers. A large body of research on public perceptions of police behaviour raises concerns about perceptions of unequal treatment of citizens by law enforcement (Carmichael et al., 2021). The COVID-19 pandemic and the protests for racial justice present important challenges to police, and also an opportunity to examine how the public perceives law enforcement. This is important because the police, now more than ever, need to ensure that their actions are procedurally just and work to build their legitimacy across the entire population they serve (Jones, 2020). The present study seeks to contribute to the literature on police legitimacy during public health emergencies and social crises. We examine whether previous experience with the police and concern over the spread of the coronavirus have an influence on perceptions of police legitimacy.

\section{The COVID-19 Pandemic, Racial Protests, and Police Legitimacy}

The racial protests against the shocking police killing of George Floyd in May 2020 unfolded within the context of the COVID-19 pandemic. This led both public health experts and policymakers to contend that exercise of the constitutional right to assemble during a pandemic would generate substantial public health costs (Dave et al., 2020). Pandemics present significant public health threats that demand a coordinated response. During public health and other emergencies, police are granted special powers to enforce mandates such as quarantines, shelter-in-place orders, and prohibitions on many gatherings and business interactions (Ligor, 2020). These powers often allow the police to arrest, detain, and even use force to ensure individual compliance. As agents of the government, the police have historically used these same powers to prevent, disperse, manage, and otherwise control protests (Maguire, 2015). Still, police often struggle with balancing the right to free expression and assembly with concerns about public safety and the maintenance of law and order (Lydon, 2018).

The key empirical issue underlying a legitimacy-based strategy of policing is whether people's views about the legitimacy of the law and the police actually shape their cooperative behaviour (Tyler, 2004). One of the most consistent findings that emerges from existing research on legitimacy suggests there are at least three unique drivers of perceptions of police fairness. These include (a) individual demographic differences, (b) prior encounters with the police, and (c) perceptions of police agency representativeness (Socia et al.,
2021). Across many different contexts, older people seem to have more favourable views of police than younger people; people who have had recent contact with the police seem to express less favourable views (the quality of the contact is also important, particularly when it comes to procedural justice); and people from ethnic and other minority groups seem to be less positive about police than those from the majority group (Bradford et al., 2017).

Media reports suggest both the COVID-19 pandemic and the protests for racial equality complicate the relationship between compliance with police authority and perceptions of police legitimacy. For example, at the height of the pandemic in New York City, Blacks and Latinos were overwhelmingly ticketed by the New York Police Department (NYPD) for physical distancing violations (Morales \& Joseph, 2020). What is more, photos and videos that showed the police behaving abusively towards peaceful protesters (Dave et al., 2020; Friedersdorf, 2012) raise important questions about the legitimacy of the American police and the limits of freedom for people interested in expressing their views through public protest (Maguire, 2015). However, research that considers police legitimacy within the context of co-occurring crises is only emerging. In particular, we know very little about how police legitimacy has been conditioned by the COVID-19 pandemic and the recent racial protests. Below we examine perceptions of police legitimacy in a sample of American adults in the context of the COVID-19 pandemic and the current period of social unrest.

\section{METHODS}

\section{Data}

This study analyzes data from the June 11-15, 2020, Associated (AP)-NORC Center for Public Affairs Research Poll. Data collection procedures for the AP-NORC Poll are fully described at https://apnorc.org/wp-content/uploads/2020/06/Topline_ final_release5.pdf, and the data are publicly accessible online. The data were collected using the AmeriSpeak Omnibus (NORC), between June 11 and 15, 2020, from adults aged 18 and over representing the 50 states and the District of Columbia. AmeriSpeak Omnibus is a monthly survey that uses NORC's probability-based panel. Panel members were randomly drawn; 1,310 completed the survey-1,220 via the web and 90 via telephone. Interviews were conducted in both English and Spanish. The final stage completion rate was $16.9 \%$, the weighted household panel response rate, $23.6 \%$, and the weighted household panel retention rate was $84.8 \%$, for a cumulative response rate of $3.4 \%$. The overall margin of sampling error is \pm 3.7 percentage points at the $95 \%$ confidence level, including the design effect. The margin of sampling error may be higher for subgroups (AP-NORC, 2020). The analytic sample for the current study consists of 1,310 respondents who have completed information on all study variables.

\section{Participants}

Approximately $12 \%$ of the respondents were Black, nonHispanic, while nearly $63 \%$ identified as white, non-Hispanic, and another $16.7 \%$ as Hispanic. Almost $60 \%$ of participants were currently employed, and nearly one-third were between the ages of 40 and 49 . More than $34 \%$ had earned a bachelor's degree or higher. Nearly $50 \%$ of participants were married and 
one-fifth reported a household income between $\$ 50,000$ and under $\$ 75,000$. More than one-third of respondents were from the US South, and only $17.4 \%$ of the respondents were from the Northwest (Table I). Although over one-third of respondents "strongly approved of the recent protests against police violence in response to Floyd's death," only 7.3\% reported participating "in any protests or demonstrations about police violence" in the few weeks preceding the survey. About one in six respondents (16.3\%) "worried about [themselves] or someone in [their] family being infected with the coronavirus."

\section{Measures}

The June 2020 AP-NORC Poll asked respondents about various themes, including contact with the police, concerns over the spread of $S A R S-C o V-2$, the virus that causes COVID-19, and perceptions of police legitimacy. The survey also collected background demographic information.

Perceived treatment by the police was assessed by asking respondents whether they had "personally ever felt treated unfairly by a police officer specifically because of [their] race?" The response options were "Yes, I have," and "No, I haven't." Concern over the spread of SARS-CoV-2 is a composite score of four items that measures respondents' views on select measures to mitigate the spread of coronavirus. These include (a) banning travel into the United States for people from other countries, (b) requiring Americans to stay in their homes except for essential errands, (c) requiring Americans to limit gatherings to 10 people or fewer, and (d) restricting travel within the United States. These items were measured on a five-point Likert scale and recoded to reflect answer choices from $1=$ strongly oppose to $5=$ strongly favour. The score yielded an internal consistency reliability score of .943 .

Perceptions of police legitimacy is a composite index constructed from four questions, with higher values signifying stronger perceptions of police legitimacy. The first question asked "how serious a problem [participants] think police violence against the public is in the United States" on a five-point Likert scale (not at all serious, not too serious, moderately serious, very serious, and extremely serious). The second question asked against whom (black people, white people, or neither) were police more likely to use deadly force. This variable was recoded and only two categories were considered: 0 = "race does not influence deadly force" and $1=$ "police are more likely to use deadly force against a black person." The third question included asked the participant's opinion on who is "treated more fairly" by the police (black people, white people, or neither). This variable was recoded into two categories: $0=$ "race does not affect how the police treat people" and $1=$ "the police treat white people more fairly." Question 4 asked whether respondents "approved, disapproved, or neither approved nor disapproved of the recent protests against police violence in response to George Floyd's death." The perception of police legitimacy scale yielded an internal consistency reliability score of .815 .

\section{RESULTS}

Table II represents the correlation matrix among the study variables. Descriptive statistics in Table II show participants' perceptions of police legitimacy were relatively high $(M=8.28$; range: 2-12). Participants also expressed a relatively high level
TABLE I Sample characteristics $(N=1,310)$

\begin{tabular}{|c|c|}
\hline Demographic Variable & $N(\%)$ \\
\hline \multicolumn{2}{|l|}{ Race/Ethnicity } \\
\hline White, non-Hispanic & $823(62.8)$ \\
\hline African American, non-Hispanic & $156(11.9)$ \\
\hline Hispanic & $218(16.7)$ \\
\hline Other & $113(8.6)$ \\
\hline \multicolumn{2}{|l|}{ Gender } \\
\hline Male & $633(48.3)$ \\
\hline Female & $677(51.7)$ \\
\hline \multicolumn{2}{|l|}{ Employment status } \\
\hline Employed & $783(59.7)$ \\
\hline Not employed & $527(40.3)$ \\
\hline \multicolumn{2}{|l|}{ Age } \\
\hline $18-29$ & $269(20.5)$ \\
\hline $30-39$ & 227 (17.3) \\
\hline $40-49$ & $435(32.4)$ \\
\hline $60-64$ & $108(8.3)$ \\
\hline 65 or older & $281(21.5)$ \\
\hline \multicolumn{2}{|l|}{ Educational attainment } \\
\hline No high school diploma & $128(9.8)$ \\
\hline High school graduate/equivalent & $370(28.2)$ \\
\hline Some college & $363(27.7)$ \\
\hline Bachelor's degree/above & 449 (34.3) \\
\hline \multicolumn{2}{|l|}{ Marital status } \\
\hline Married & $650(49.6)$ \\
\hline Widowed & $59(4.5)$ \\
\hline Divorced & 144 (11.0) \\
\hline Separated & $25(1.9)$ \\
\hline Never married & $328(25.0)$ \\
\hline Living with partner & $104(8.0)$ \\
\hline \multicolumn{2}{|l|}{ Household income } \\
\hline Under $\$ 10,000$ & $87(6.6)$ \\
\hline$\$ 10,000$ to under $\$ 20,000$ & $106(8.1)$ \\
\hline$\$ 20,000$ to under $\$ 30,000$ & $161(12.3)$ \\
\hline$\$ 30,000$ to under $\$ 40,000$ & $101(7.7)$ \\
\hline$\$ 40,000$ to under $\$ 50,000$ & $111(8.5)$ \\
\hline$\$ 50,000$ to under $\$ 75,000$ & $273(20.8)$ \\
\hline$\$ 75,000$ to under $\$ 100,000$ & $182(13.9)$ \\
\hline$\$ 100,000$ to under $\$ 150,000$ & $168(12.8)$ \\
\hline$\$ 150,000$ or more & $122(9.3)$ \\
\hline \multicolumn{2}{|l|}{ Region } \\
\hline Northwest & $228(17.4)$ \\
\hline Midwest & $272(20.7)$ \\
\hline South & 498 (38.0) \\
\hline West & $312(23.8)$ \\
\hline
\end{tabular}


of concern over the spread of SARS-CoV-2 $(M=13.85$; range = $3-20)$. Perceptions of police legitimacy had low $(r \leq .10)$ to moderate $(r \sim$.30) (Cohen, 2013; McPhail et al., 2017) correlations with participants' concern over the spread of COVID-19 $(r=.336)$, perceived treatment by the police $(r=.218)$, race/ ethnicity $(r=.172)$, gender $(r=.071)$, and marital status $(r=-.116)$. Race and perceived treatment by the police were strongly correlated $(r=.362)$. Age $(r=-.155)$ and marital status $(r=-.116)$ were each negatively correlated with perceptions of police legitimacy. A graphical illustration of the relationship between police legitimacy and concern over COVID-19 for study participants is provided in Figure 1.

\section{Hierarchical Multiple Regression Analyses}

Hierarchical multiple regressions (HMRs) were performed to examine the relationship between criterion variables (personal experience with the police and concern over the spread of coronavirus) and perceptions of police legitimacy

TABLE II Descriptive statistics, correlations, and reliability scores for study variables

\begin{tabular}{|c|c|c|c|c|c|c|c|c|c|c|c|c|c|c|}
\hline \multirow[t]{2}{*}{ Variables } & \multirow[t]{2}{*}{$M$} & \multirow[t]{2}{*}{ SD } & \multirow[t]{2}{*}{ Range } & \multirow[t]{2}{*}{$\beta$} & \multirow{2}{*}{$\begin{array}{l}\text { Number } \\
\text { of items }\end{array}$} & \multicolumn{9}{|c|}{ Correlations } \\
\hline & & & & & & 1 & 2 & 3 & 4 & 5 & 6 & 7 & 8 & 9 \\
\hline $\begin{array}{l}\text { Perceptions of police } \\
\text { legitimacy }\end{array}$ & 8.28 & 2.92 & $2-12$ & .815 & 4 & 1 & $.336^{* *}$ & $.218^{* *}$ & $-.155^{\text {** }}$ & .020 & $.172^{* *}$ & -.015 & $.071^{*}$ & $-.116^{* *}$ \\
\hline $\begin{array}{l}\text { Concern over the } \\
\text { spread of SARS-CoV-2 }\end{array}$ & 13.85 & 4.13 & $3-20$ & .943 & 3 & & 1 & $.156^{\star \star}$ & -.036 & $-.076^{* *}$ & $.166^{* *}$ & $-.060^{*}$ & $.095^{* \star}$ & -.032 \\
\hline $\begin{array}{l}\text { Perceived treatment by } \\
\text { the police }\end{array}$ & & & & & & & & 1 & $-.108^{\star \star}$ & -.050 & $.362^{* \star}$ & $-.128^{* *}$ & .003 & $-.127^{\star \star}$ \\
\hline Age group & & & & & & & & & 1 & $.146^{* *}$ & $-.171^{\star *}$ & .052 & .020 & $.254^{* *}$ \\
\hline Educational attainment & & & & & & & & & & 1 & $-.114^{\star *}$ & $.339^{* *}$ & -.014 & $.195^{* *}$ \\
\hline Race/Ethnicity & & & & & & & & & & & 1 & $-.204^{* *}$ & -.021 & $-.150^{* *}$ \\
\hline Household income & & & & & & & & & & & & 1 & $-.146^{\star *}$ & $.369^{* *}$ \\
\hline Gender & & & & & & & & & & & & & 1 & $-.074^{* *}$ \\
\hline Marital status & & & & & & & & & & & & & & 1 \\
\hline
\end{tabular}

${ }^{*} p<.05 .{ }^{* *} p<.01 .{ }^{* *} p<.001$

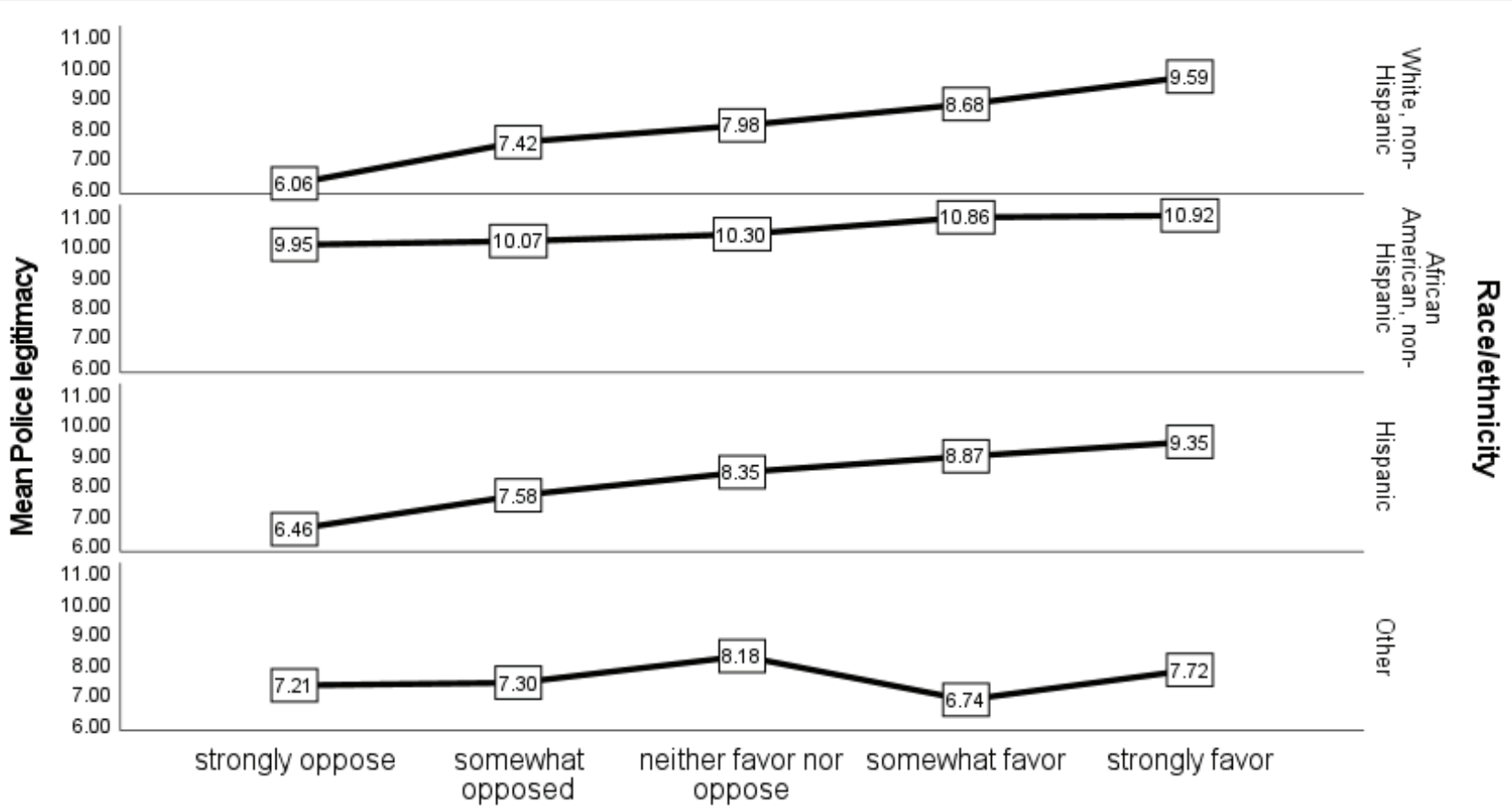

Concern with COVID-19

FIGURE 1 Differences in perceptions of police legitimacy by concern over COVID-19, as determined by agreement with or opposition to measures to mitigate the spread of the virus. 
(dependent variable), after controlling for the effects of race/ ethnicity, gender, age, educational attainment, marital status, and household income. Diagnostic tests for using HMR showed very little missing data (less than $2 \%$ ), no multicollinearity, and that all assumptions were met. Two HMR models were constructed. Model 1 entered demographic variables, and Model 2 added personal experience with the police and concern over the spread of coronavirus to Model 1.

Age, educational attainment, race/ethnicity, household income, gender, and marital status were entered in the first step of the hierarchical linear regression model (see Table III). These sociodemographic variables explained a small but statistically significant portion of the variance in perceptions of police legitimacy $\left(\mathrm{R}^{2}=.061, p<.001\right)$. Age $(\beta=-.119$, $p<.001)$, educational attainment $(\beta=.057, p<.05)$, gender $(\beta=.069, p<.05)$, and marital status $(\beta=-.089, p<.01)$ had small but statistically significant effects on perceptions of police legitimacy. These results suggest respondents who reported lower perceptions of police legitimacy were older and unmarried. Perceptions of police legitimacy were high among female and non-white respondents and among those with higher educational attainment.

Perceived treatment by the police and concern over the spread of SARS-CoV-2 were entered in the second step of the analysis. They added considerably to the variance explained in police legitimacy $\left(\mathrm{R}^{2}=.172, \Delta \mathrm{R}^{2}=.112, p<.001\right)$. These variables dramatically increased the explanatory power $\left(\mathrm{R}^{2}\right)$ of the independent variables by nearly $48 \%$ to .172 . The potency of perceived treatment by the police $(\beta=.137, p<.001)$ and concern over the spread of SARS-CoV-2 $(\beta=.302, p<.001)$ nullified the effect of gender and altered that of race $(\beta=-.059$, $p<.05)$ on perceptions of police legitimacy. The effects of age and educational attainment were also slightly reduced after adding perceived treatment by the police and concerns over the spread of SARS-CoV-2 to the model. The effects of gender and race found in Model 1 are thus entirely attributable to gender and race differences in perceived treatment by the police and in concern over the spread of SARS-CoV-2. Similarly, some of the effects of age and education reflect instead differences by age and education in perceived treatment by the police and in concern over the spread of SARS-CoV-2.

Our final assessment of the total model provides two interesting insights. First, concern over the spread of SARS$\mathrm{CoV}-2$ emerged as the most important predictor of perceptions of police legitimacy within the contexts of a pandemic and racial protests. Second, white, non-Hispanic respondents $(\beta=-.059, p<.05)$ present with higher perceptions of police legitimacy, as demonstrated by the change in the relationship between race and the dependent variables from Model 1 to Model 2.

\section{DISCUSSION}

Before addressing the implications of our research, we present some of our study's limitations. Using secondary data is challenging because the specific information needed to answer the research questions is often not available. The use of cross-sectional data is also problematic since it represents a single point in time. For instance, longitudinal data would have allowed us to measure perceptions of police legitimacy over time, particularly for respondents who report multiple encounters with the police. A longitudinal measure of concern over the spread of coronavirus would have been especially useful in ascertaining changes over the course of the pandemic, including during the racial protests. We also believe that our results were influenced by the demographic

Table III Hierarchical regression analyses for variables predicting perceptions of police legitimacy

\begin{tabular}{|c|c|c|c|c|c|c|c|}
\hline Variables & $\beta$ & $\mathbf{R}$ & $\mathbf{R}^{2}$ & $\Delta \mathbf{R}^{2}$ & $\Delta \mathbf{F}$ & df1 & $\mathrm{df2}$ \\
\hline Step 1 & & .246 & .061 & .061 & $13.87^{* * *}$ & 6 & 1290 \\
\hline Age & $-.119 * * *$ & & & & & & \\
\hline Educational attainment & $.057^{*}$ & & & & & & \\
\hline Race/Ethnicity & $.153^{* * *}$ & & & & & & \\
\hline Household income & .043 & & & & & & \\
\hline Gender & $.069 *$ & & & & & & \\
\hline Marital status & $-.089 * *$ & & & & & & \\
\hline Step 2 & & .415 & .172 & .112 & $87.05^{* * *}$ & 2 & 1288 \\
\hline Age & $-.112 * * *$ & & & & & & \\
\hline Educational attainment & $.072 * *$ & & & & & & \\
\hline Race/Ethnicity & $-.059 *$ & & & & & & \\
\hline Household income & .050 & & & & & & \\
\hline Gender & .043 & & & & & & \\
\hline Marital status & $-.085^{\star *}$ & & & & & & \\
\hline Perceived treatment by the police & $.137 * \star \star$ & & & & & & \\
\hline Concern over the spread of SARS-CoV-2 & $.302 * * *$ & & & & & & \\
\hline
\end{tabular}


composition of our sample. More than $36 \%$ of our respondents reported a household income that far exceeds the national median household income of $\$ 68,703$ for 2019 (Rothbaum, 2020). Even with these limitations, our results add to the body of knowledge on public health emergencies and social crises.

The current study sought to describe perceptions of police legitimacy in a sample of American adults in the context of the COVID-19 pandemic and the current period of social unrest. Findings suggest respondents' perceptions of police legitimacy were high, particularly a mong those who reported being married. Very little is known about how marriage shapes perceptions of police legitimacy. Hawdon et al.'s (2003) analysis of policing tactics and perceptions of police legitimacy established a negligible correlation $(r=.121)$ between marital status and trust in the police. Although unexpected, this finding underscores the need to further explore the relationship between marital status and perceptions of police legitimacy.

Older participants reported lower perceptions of police legitimacy. This finding was unanticipated because it contradicts earlier work showing younger people are more disengaged from police, who they also view as illegitimate (Madon et al., 2017). A positive association was identified between educational attainment and perceptions of police legitimacy. For our sample, this means having a high school education and having earned a higher degree is associated with higher perceptions of police legitimacy. This result contradicts prior findings of an adverse relationship between educational attainment and legitimacy. Antrobus et al. (2015) found that individuals with a higher level of education were significantly more likely to feel less obligated to obey police.

Perceived treatment by the police and concern over the spread of the coronavirus emerged as statistically significant predictors of legitimacy. Even respondents who answered in the affirmative when asked if they had "personally ever felt treated unfairly by a police officer specifically because of [their] race" reported high perceptions of police legitimacy. Although counterintuitive, this finding suggests that perceptions of legitimacy may be less driven by personal experiences with the police than by publicized events. This also holds true for respondents who reported that they felt unfairly treated by the police because of their race.

Our findings more immediately suggest further analysis on whether the differential effects of perceived treatment by the police and concern over the spread of SARS-CoV-2 in Model 2 versus Model 1 operate primarily through effects on race (Blacks/ minorities) for perceived treatment by the police and on gender (women of all races) for concern over the spread of SARS-CoV-2. We hope future perception studies expand analyses of associations of demographic factors with legitimacy to disaster and post-disaster periods, which often require curfews and assembly limitations. Qualitative approaches should also consider exploring nuances of perceptions of police legitimacy, such as views on the emergency powers that the police are granted during public and social crises.

Based on our findings, we submit that, even when public health imperatives underpin police action to uphold order, public trust for the legitimacy of their actions is not automatically forthcoming (Koehler, 2020). Further, the use of militarized policing tactics such as firing chemical irritants and using aggressive tactics against protesters can leave already aggrieved citizens feeling even more humiliated, violated, or even victimized (Mockaitis, 2020). This points to a need for the police to provide services in a constitutionally lawful and morally upright way (Stoughton et al., 2020). To that end, the police could survey citizens on policing in general and on specific tactics in particular. To improve on legitimacy, the police could report results and identify actions that will be taken to foster favourable citizen responses and remediate negative responses (Gau \& Brunson, 2010). This is particularly critical in times of converging crises, when the government and law enforcement agencies should be focused more on providing services and protection than on executing a hardline approach to law and order.

\section{CONFLICT OF INTEREST DISCLOSURES}

The authors have no conflicts of interest to declare.

\section{AUTHOR AFFILIATIONS}

*Department of Sociology and Criminology, Howard University, Washington, DC, USA.

\section{REFERENCES}

Antrobus, E., Bradford, B., Murphy, K., \& Sargeant, E. (2015). Community norms, procedural justice, and the public's perceptions of police legitimacy. Journal of Contemporary Criminal Justice, 31 (2), 151-170.

AP-NORC. (2020, June 11). The June 2020 AP-NORC Center Poll. https://apnorc.org/wp-content/uploads/2020/06/Topline_final_ release5.pdf.

Bittner, E. (1970). The functions of the police in modern society: A review of background factors, current practices, and possible role models. University of Michigan Library.

Bradford, B., Jackson, J., \& Hough, M. (2017). Ethnicity, group position and police legitimacy. In D. Oberwittler and S. Roché (Eds.), Policecitizen relations across the world: Comparing sources and contexts of trust and legitimacy (pp. 70-96). Routledge.

Carmichael, J., David, J. D., Helou, A. M., \& Pereira, C. (2021). Determinants of citizens' perceptions of police behavior during traffic and pedestrian stops. Criminal Justice Review, 46(1), 99-118. https:// doi.org/10.1177/0734016820952523

Cohen, J. (2013). Statistical power analysis for the behavioral sciences. Academic press.

Culhane, S. E., Boman IV, J. H., \& Schweitzer, K. (2016). Public perceptions of the justifiability of police shootings: The role of body cameras in a pre-and post-Ferguson experiment. Police Quarterly, 19(3), 251-274.

Dave, D. M., Friedson, A. I., Matsuzawa, K., Sabia, J. J., \& Safford, S. (2020). Black lives matter protests and risk avoidance: The case of civil unrest during a pandemic. National Bureau of Economic Research Working Paper Series.

Friedersdorf, C. (2012, July 25). 14 specific allegations of NYPD brutality during Occupy Wall Street. The Atlantic. https://www.theatlantic. $\mathrm{com} /$ politics/archive/2012/07/14-specific-allegations-of-nypdbrutality-during-occupy-wall-street/260295/

Gau, J. M., \& Brunson, R. K. (2010). Procedural justice and order maintenance policing: A study of inner-city young men's perceptions of police legitimacy. Justice Quarterly, 27(2), 255-279. https://doi. org/10.1080/07418820902763889

Hawdon, J. E., Ryan, J., \& Griffin, S. P. (2003). Policing tactics and perceptions of police legitimacy. Police Quarterly, 6(4), 469-491.

Henry, T. K. S., \& Franklin, T. W. (2019). Police legitimacy in the context of street stops: The effects of race, class, and procedural justice. Criminal Justice Policy Review, 30131, 406-427. 
POLICE, PANDEMIC, AND SOCIAL UNREST, Jipguep-Akhtar et al.

Hinds, L., \& Murphy, K. (2007). Public satisfaction with police: Using procedural justice to improve police legitimacy. Australian \& New Zealand Journal of Criminology, 40(1), 27-42.

Hoggett, J., \& Stott, C. (2010). The role of crowd theory in determining the use of force in public order policing. Policing and Society, 20(2), 223-236. https://doi.org/10.1080/10439461003668468

Johnson, D., Maguire, E. R., \& Kuhns, J. B. (2014). Public perceptions of the legitimacy of the law and legal authorities: Evidence from the Caribbean. Law \& Society Review, 48(4), 947-978.

Jones, D. J. (2020). The potential impacts of pandemic policing on police legitimacy: planning past the COVID-19 crisis. Policing: A Journal of Policy and Practice, 14(3), 579-586.

Koehler, J. (2020). Why are we witnessing a resurgence in \#BlacklivesMatter (\#BLM) protests now? Is something distinctive happening? https://blogs. Ise.ac.uk/usappblog/2020/06/05/the-latest-blacklivesmatterprotests-highlight-how-american-policing-falls-short-of-its-charg

Ligor, D. C. (2020). State police powers: A less than optimal remedy for the COVID-19 disease. RAND. https://www.rand.org/blog/2020/05/ state-police-powers-a-less-than-optimal-remedy-for.html

Lydon, D. (2018). Police legitimacy and the policing of protest: Identifying contextual influences associated with the construction and shaping of protester perceptions of police legitimacy and attitudes to compliance and cooperation beyond the limits of procedural justice. Canterbury Christ Church University.

Madon, N. S., Murphy, K., \& Sargeant, E. (2017). Promoting police legitimacy among disengaged minority groups: Does procedural justice matter more? Criminology \& Criminal Justice, 17|51, 624-642.

Maguire, E. R. (2015). New directions in protest policing. Saint Louis University Public Law Review, 35, 67.

McPhail, I. V., Olver, M. E., \& Brooks, C. (2017). Taking the pulse: Perceptions of crime trends and community safety and support for crime control methods in the Canadian Prairies. Journal of Community Safety and Well-Being, 2(2), 43-50.

Metcalfe, C., \& Pickett, J. (2020). Public fear of protesters and support for protest policing: An experimental study. Working Paper, University of South Carolina. https://doi.org/10.31235/osf.io/7hcwp
Mockaitis, T. (2020). Policing, pandemic and the American racial divide. https://nbn-resolving.org/urn:nbn:de:0168-ssoar-68448-1

Morales, M., \& Joseph, E. (2020, May 9). Over $80 \%$ of social distancing summons given to Blacks and Latinos. CNN. https://www.cnn. com/2020/05/08/us/social-distancing-stats-nyc/index.html

Murray, K. H. (2010). Police legitimacy and policing public protest. University of Edinburgh School of Law Working Paper, 36.

Nix, J., Ivanov, S., \& Pickett, J. T. (2021). What does the public want police to do during pandemics? A national experiment. Criminology and Public Policy, 1-27. https://doi.org/10.1111/1745-9133.12535

Pica, E., Thompson, L. E., Pozzulo, J., \& Sheahan, C. L. (2019). Perceptions of police conduct when race and gender are considered. Journal of Police and Criminal Psychology, 1-15.

Rothbaum, J. (2020, September 15). Was household income the highest ever in 2019? US Bureau of Census. https://www.census.gov/ Income2020

Socia, K. M., Morabito, M. S., Bond, B. J., \& Nader, E. S. (2021). Public perceptions of police agency fairness and the willingness to call police. The American Review of Public Administration, 02750740211005699.

Stoughton, S. W., Noble, J. J., \& Alpert, G. P. (2020, June 3). How to actually fix America's police. The Atlantic. https://www. the atlantic.com/ideas/archive/2020/06/how-actually-fix-americaspolice/612520/

Sunshine, J., \& Tyler, T. R. (2003). The role of procedural justice and legitimacy in shaping public support for policing. Law \& Society Review, 37(3), 513-548

Szabo, L., Hancock, J., Slack, D., \&Wagner, D. (2020, June 19). Fractured skulls, lost eyes: Police often break own rules using "rubber bullets." Kaiser Health News. https://khn.org/news/rubber-bullets-protesterspolice-often-violate-own-policies-crowd-control-less-lethal-weapons/

Tyler, T. R. (2004). Enhancing police legitimacy. The Annals of the American Academy of Political and Social Science, 593(1), 84-99.

Wortley, S., \& Owusu-Bempah, A. (2009). Unequal before the law: Immigrant and racial minority perceptions of the Canadian criminal justice system. Journal of International Migration and Integration/Revue de I'integration et de La Migration Internationale, 10(4), 447-473. 